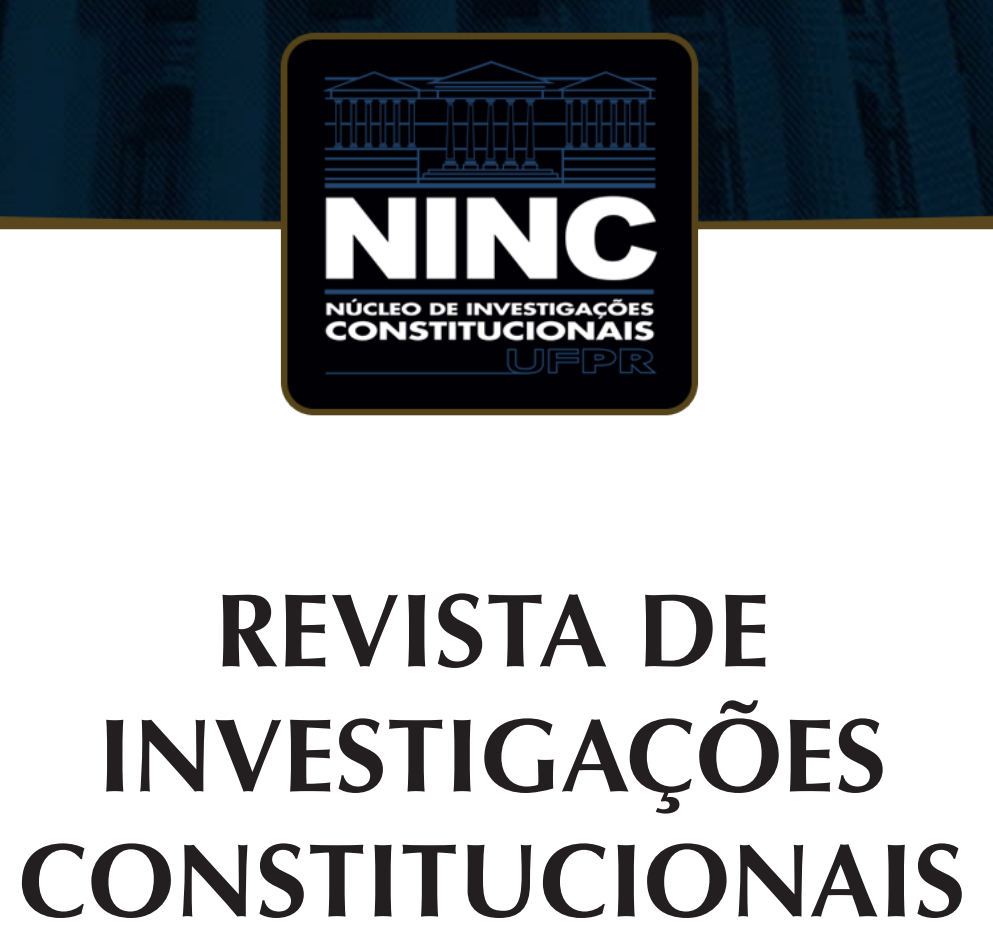

JOURNAL OF CONSTITUTIONAL RESEARCH

vol. 5 | n. 1 | janeiro/abril 2018 | ISSN 2359-5639 | Periodicidade quadrimestral Curitiba | Núcleo de Investigações Constitucionais da UFPR | www.ninc.com.br 


\section{From an idealized separation of powers to its practical problems in the Rule of Law}

\section{De uma idealizada separação dos poderes aos seus problemas práticos no Estado de Direito}

\section{CÉSAR AUGUSTO CICHELERO*}

Universidade de Caxias do Sul (Brasil) http://orcid.org/0000-0002-1454-4231

cesar.cichelero@gmail.com

\section{CAROLINE FERRI**}

Universidade do Estado do Rio de Janeiro (Brasil) http://orcid.org/0000-0002-3970-6751

carolineferri@gmail.com

\section{EDUARDO BRANDÃO NUNES***}

Universidade Federal do Rio de Janeiro (Brasil) http://orcid.org/0000-0002-7580-0649 ebnunes@hotmail.com

Recebido/Received: 24.10.2017 / October 24th, 2017 Aprovado/Approved: 31.12.2017 / December 31st, 2017

Como citar esse artigo/How to cite this article: CICHELERO, César Augusto; FERRI, Caroline; NUNES, Eduardo Brandão. From an idealized separation of powers to its practical problems in the Rule of Law. Revista de Investigações Constitucionais, Curitiba, vol. 5, n. 1, p. 15-40, jan./abr. 2018. DOI: 10.5380/rinc.v5i1.55929.

*Mestrando em Direito pela Universidade de Caxias do Sul (Caxias do Sul, RS, Brasil) no período de 2017/2018 e taxista da CAPES. Possui graduação em Direito pela Universidade de Caxias do Sul (UCS) em 2016. E-mail: cesar.cichelero@gmail.com.

** Professora Adjunta da Universidade do Estado do Rio de Janeiro (Rio de Janeiro, RJ, Brasil), atuando nos cursos de graduação, mestrado e doutorado em Direito. Doutora em Direito pela Universidade Federal de Santa Catarina (Florianópolis, SC, Brasil) (2012). Possui graduação em Direito pela Universidade do Vale do Itajaí (2003), graduação em Filosofia pela Universidade Federal de Santa Catarina (2004) e mestrado em Direito pela Universidade Federal de Santa Catarina (2006). E-mail: carolineferri@ gmail.com.

**** Mestrando em Direito pela Universidade Federal do Rio de Janeiro (Rio de Janeiro, RJ, Brasil). Bacharel em Direito pela Universidade de Caxias do Sul. Bolsista CAPES. E-mail: ebnunes@hotmail.com. 
Abstract

The paper presents the Separation of Powers as a principle. It means that it is one of several possible political choices. We take this conception and then we aim to explain how it develops with relevance in a Rule of Law and its procedures. It was analytically perceived that such conception is idealized because it fails to address practical problems. The main problematic confronted is in relation to the activity of the Judiciary, exemplified through Brazilian conflicts between the different powers, in this paper we approach, for this purpose, the vaquejada case. In order to try to overcome such problems, the presented hypothesis is that a dialogic theory can provide some answers by promoting dialogue through equilibrium and partnership between the powers and citizens.

Keywords: Rule of Law; separation of powers; articulated governance; vaquejada; dialogic theory.

\section{Resumo}

O artigo apresenta a Separação de Poderes como um princípio. Isso significa que é uma das várias opções políticas possíveis. Tomamos essa concepção e então objetivamos explicar como ela se desenvolve com relevância em um Estado de Direito e seus procedimentos. Foi percebido analiticamente que essa concepção é idealizada pois falha em abordar problemas práticos. A principal problemática confrontada é em relação à atividade do Judiciário, exemplificada por conflitos brasileiros entre os diferentes poderes, neste trabalho se aborda, para tanto, o caso da vaquejada. Para tentar superar esses problemas, a hipótese apresentada é que uma teoria dialógica pode fornecer algumas respostas promovendo o diálogo através do equilíbrio e da parceria entre os poderes e os cidadãos.

Palavras-chave: Estado de Direito; separação dos poderes; governança articulada; vaquejada; teoria dialógica.

\section{CONTENTS}

1. Introduction; 2. Idealized vision: Separation of Powers as a political principle; 3. Essential relationship with the Rule of Law and its procedures; 4. Problems with the idealization and the Separation of Powers in the Brazilian State; 5. Exemplifing a practical problem: The clash over the case of the "vaquejada"; $\mathbf{6}$. Possibility to overcome the problems and limitations; 7. Final considerations; 8. References.

\section{INTRODUCTION}

The theme of the present paper is the Separation of Powers, as a principle, and how its essence lies in a qualitative separation of the different functions of government. The notion of Separation of Powers analytically presented here, which will initially be called idealized, refers mainly to the conception of Jeremy Waldron and his relation with classic works of Montesquieu and Locke. Waldron develops the ideal Separation of Powers, aiming at its pure form, we then take that idealized conception and part to elaborate how this would unwind and its relevance in the Rule of Law

It is also highlighted how such conception has direct connection with the Rule of Law and its procedures, propitiating an articulated governance through successive phases. The contrast between the Law and the arbitrary exercise of power has to do with institutions and its procedures, which are established with the help of the Separation of Powers. These procedures become inherent aspects of the Law, and disrespecting one of them is disrespecting the Rule of Law itself.

We then part to demonstrate some of the limitations and problems that an idealized conception of the Separation of Powers faces. It should be noted here that the purpose of this paper is to reaffirm this separation as essential, but not in the idealized 
way, making it necessary first to understand how the idealization occurs so that it is possible to find ways to bring the separation closer to institutional realities.

The problem found in the idealization is mainly in relation to the activity of the Judiciary as preponderant in the contemporaneity, through the use of judicial review and constitutional interpretation, what may be called judicial activism. Examples were found in Brazilian Law that demonstrate the tension and conflicts between powers. We don't try do deny that the judiciary plays an important role in the Rule of Law, but we do see as essential that its role becomes more flexible so that the other powers can participate more, for they are the proper centers for broad debates. The main tensions happen between powers when one of them sets constitutional meaning while the others disagree.

One practical problem exemplified here was the clash over the case of the "vaquejada" in Brazil, that had a state law appreciated by the Federal Supreme Court and end up causing a direct clash with the Congress for the Constitutional meaning present in rules that were colliding in the practical case. Such clash made the Congress leave its inertia - only after the courts decision - to give a response, almost in a power struggle to set constitutional meaning.

In order to try to overcome such problems, the hypothesis put forward is that a dialogic theory can give an adequate, but yet incomplete, response to a functional Separation of Powers, based on a dialogue through a theory that fuses equilibrium and partnership. The constitutional meaning is not only a matter of interpretation for the powers, but for the citizens as well. Combining democracy and different institutions is an important step in order to promote a practical separation of powers.

\section{IDEALIZED VISION: SEPARATION OF POWERS AS A POLITICAL PRINCIPLE}

Understanding the Separation of Powers as a political principle entails it being only one principle among several others. Other principles as important as the Separation of Powers can be listed, and they also play an important role in maintaining an institutional legitimacy needed in the Rule of Law. Some of them communicate directly with the Separation of Powers and can cause confusion, and therefore, are worth mentioning here to be differentiated from the meaning proposed to the Separation of Powers. One of these principles is the Division of Power, meaning that there can be no concentration of political power in the hands of a single person, group or institution in order to avoid possible oppression or tyranny.

The Division of Power only cares about such power being divided, in no matter what way. Such is the difference regarding the Separation of Powers, that defining the taxonomy and how the power will not be concentrated are the conceptions that 
matter. Endorsing such view, Jeremy Waldron argues that if "we want to divide power up, what would be better than to begin by dividing the power of a judge from that of a legislator and from that of an executive official?"1. But the division in such a defined manner is not just a matter for the principle of Division of Powers, and Waldron would probably agree.

A second principle worth mentioning are the checks and balances, referring that one power must concur in the others actions. Such principle implies the duty of a power supervising the other actions, possibly vetoing and questioning the choices made. On this account, what matters is how a power can balance another, as of the powers are already dispersed and with well defined scopes of action to take care of. Lastly, we appoint the Federalism as a political principle that serves the purpose of distinguishing the institutional powers of the federal government in relation to the states and cities. Differences made, it's important to mention that the Separation of Powers as a political principle is just one of a set of principles that compose the contemporary state, and that sometimes it may overlap with the previous cited principles - and possibly other principles not mentioned as well.

Waldron's account on this sense is essential, because as he says, "to insist on being ruled by law is, among other things, to insist on being ruled by a process that answers to the institutional articulation required by separation of powers" 2 . This idealized vision of the Separation of Powers, is a manner of providing an articulated form of governance by establishing clearly who are the powers being created and what they can do. Reducing the amount of power one can exercise at a time ends up being a form of minimizing risks to freedom - both individual and collective - or that different interests from the majority are demoted. Such an articulated governance is important so there can be practical security against any form of concentrated power, for the classical thought comprises that "instead of tradition, the social contract; instead of the sovereignty of the prince, national sovereignty and the law as an expression of the general will"3.

The Separation of Powers brought here is a thought "which distinguishes these functions for what they are, not what they can do to hold one another in check"4. This conception of the Separation of Powers maintains that dispersing the power in different bodies may, in practice, cause some forms of conflicts. But such conflicts may be seen as positive in that sense that conflict can generate debate, so the issues can be

\footnotetext{
1 WALDRON, Jeremy. Separation of Powers in Thought and Practice. Boston College Law Review, Boston, v. 52, n. 2, p. 433-468, 2013. p. 440.

2 WALDRON, Jeremy. Political Political Theory: Essays on Institutions. Cambridge: Harvard University Press, 2016, p. 64

3 MIRANDA, Jorge. Teoria do estado e da constituição. Rio de Janeiro: Forense, 2003. p. 44.

4 WALDRON, Jeremy. Separation of Powers in Thought and Practice. Boston College Law Review, Boston, v. 52, n. 2, p. 433-468, 2013. p. 442.
} 
seen with more depth and so be better resolved - although in practice such view is controversial.

Another important feature that the Separation of Powers brings to the Rule of Law is the possibility of multiple centers of resources. If the actions of a power are deemed not satisfactory, citizens will have other centers of power to resource to. In this scenario different possibilities arise, and so the role that the Separation of Powers plays is in establishing the procedures in which such resources can happen, while not overstepping each others powers and decisions. It is then possible to perceive that "the diffusion of authority among different centres of decision-making is the antithesis of totalitarianism or absolutism"5.

This Separation of Powers tries to be functional as it will be demonstrated. It must be connected with a sort of legislative supremacy, in the sense that only through previously established laws there can be action of other powers. It is also less likely to exist oppressive legislation if the lawmakers themselves are subject to the laws they pass, while they can't administrate or execute such laws by themselves. Corroborating such idea, Locke though that if the same body could make laws and execute them "they may exempt themselves from obedience to the Laws they make, and suit the Law, both in its making and execution, to their own private advantage"6. Montesquieu, in the Spirit of the Laws, also expressed the same concerns7, although the justification for such concerns are disputable8.

Not only laws are necessary and must previous to the actions of a power, it is also necessary that every single sort of government action to be scoped and conducted in the forms of the Law and its principles as a whole. Legislation must authorize government action that will be further realized, and so conducting all action under the Law makes it possible to avoid other powers to question the legitimacy of an action in the first place. The principle of the Separation of Powers divides the process of governance in to mainly three different functions, which are "enacting a law, adjudicating disputes on the basis of a law, and administering a legal decision"9. Such order is not random, each phase of the governance is important in itself, creating a need to be respected and followed, in a process that gives a say to each power before impacting the citizens life. That is the character of articulated governance brought by the Separation of Powers.

\footnotetext{
5 VILE, Maurice J. C. Constitutionalism and the separation of powers. Indianapolis: Liberty Found. Inc., 1998. p. 16.

6 LOCKE, John. Two Treatises of Government. Cambridge: Cambridge University Press, 1988. p. 364.

7 MONTESQUIEU, Charles Louis de Secondat. Do espírito das Leis. São Paulo: Martins Fontes, 2000. p. 168.

8 Jeremy Waldron exhibits the lack of clarity and tautologies present in the classical works, specially of Montesquieu, regarding the Separation of Powers and the justification for its necessity and procedures. While agreeing with the classical works, Waldron also does a great job in giving light to the points that had substantial open matters. For more depth, check JEREMY, Waldron. Political Political Theory: Essays on Institutions. Cambridge: Harvard University Press, 2016. p. 58-62.

9 WALDRON, Jeremy. Separation of Powers in Thought and Practice. Boston College Law Review, Boston, v. 52, n. 2, p. 433-468, 2013. p. 456.
} 
Rules must not only be promulgated previously, but also openly, so the citizens can know about them. This constitutes an important process that must also give time before implementation, so that the rules can be comprehended and internalized. This process would allow people to organize their conducts regarding their private life and business, while government would "begin the process of weaving these norms into the broader fabric of their supervision of various aspects of social life and begin developing strategies for (as it might be) inspection and enforcement" 10 . Such a process represents a form of an institutional articulation, that is in fact, a need for the Separation of Powers in this idealized view.

Being under the Rule of Law requires that the acting of this process must be in the order of prior legislation then adjudication or administration; or the due process and then adjudication that generates the enforceability of a decision. Thus, disregarding this process is disrespecting the Rule of Law itself, and not even a legitimate authority - not even by the force of its democratic credentials - can interfere in this process without generating this problem. And so "the Rule of Law is violated when the institutions that are supposed to embody these procedural safeguards are undermined or interfered with"11.

Even more, it is possible to characterize formal forms of government as needed, for any kind of power to be conferred can only happen by the Law; And only exercised according to its procedures (corresponding to the German concept of Reechtsstaat), as well as in a more substantial sense of limitation by the Law and its contents (which would characterize the traditional English use of the Rule of Law or the italian Statodidiritto).

Attempts are made to avoid a legislative process in which enacted laws serve only the interests of the executive branch in conducting its administration; or judicial decisions to override the legislative elaborations or the discretion of the administration. The Separation of Powers should therefore enhance the distinct character of each of these powers and their essential functions to the Rule of Law.

Initially, each power must be concerned with exercising its functions solely and exclusively. The legislature needs to be concerned with creating laws, in generic ways with a certain abstraction, so as not to adorn a person or more people in specific situations. The judiciary in judging the case of each subject and their respective relationship with the laws promulgated by the legislature. And the executive, in addition to the administration, must develop comprehensive strategies for the implementation

\footnotetext{
10 WALDRON, Jeremy. Separation of Powers in Thought and Practice. Boston College Law Review, Boston, v. 52, n. 2, p. 433-468, 2013. p. 458.

11 WALDRON, Jeremy. The Concept and the Rule of Law. Public Law and Legal Theory Research Paper. Working Papers n. $08-50,2008$, p. 7.
} 
of enacted laws. Thus, as far as possible, it is necessary to separate, in addition to the articulated processes of governance, the people who execute them ${ }^{12}$.

For example, the principle of the Separation of Powers would be indifferent to delegations since the institution to which it was delegated maintained the pure and distinct character, uncontaminated by another power. It is essential to understand that "the separation of powers is not only the division of functions, although this seems logical and efficient"13. What matters in the principle of the Separation of Powers is that there is a separation between the legislative stage, the administration and the judgment of these laws. Through this, it protects not only the processes that form the laws, but also the normative expectations of the subjects ${ }^{14}$, and consequently the Rule of Law; for "if there were no institutionalized patterns of behavior. there would be no predictability" 15 and ultimately, no Rule of Law.

\section{ESSENTIAL RELATIONSHIP WITH THE RULE OF LAW AND ITS PROCEDURES}

The Rule of Law is one of the most important political ideals of our time. It is a set of constitutive ideas of contemporary political morality. Firstly, it is necessary to recognize that there are many conceptions present in philosophy of what in fact would be a Rule of Law. Moreover, within that State ruled by the Law what would be the characteristics inherent to it. In general, "the principle of separation of powers contributes significantly, as part of the broader concept of the liberal rule of law"16. However, the focus of this paper is not on the formal and substancial aspects that a State ruled by Law should contain. So what we want to highlight are the procedures that a State performs that are what translate both the formal elements and substances to the social reality.

The understanding of the Rule of Law referred here emphasizes not only the value of established rules, the predictability they make possible, but also the importance of the procedural and argumentative aspects of legal practice. Thus, it is emphasized that there is few indications in political theory that the procedures themselves, and the rights and powers associated therewith, would be a direct part of what is assessed as a "Rule of Law", but rather as a consequence of this.

\footnotetext{
12 Contamination here regards that each power has a core of its own and a specific purpose. This transit of subjects between powers is a form of contamination of different purposes, since individuals carry with them the specific functions of the powers to which they are attached and consequently cannot escape them.

13 ROCHA, Manoel Ilson Cordeiro. Estado e governo: diferença conceitual e implicações práticas na pós-modernidade. Revista UNIARA, [s.I.], v. 21/22, p. 140-145, 2009. p. 143.

14 The important relation between expectations and the Rule of Law have determining discussions with Harts book Concept of the Law (1996) and from that point have since been extended to a point beyond what the present work can develop.

15 VILE, Maurice J. C.. Constitutionalism and the separation of powers. Indianapolis: Liberty Found. Inc., 1998. p. 407.

16 BONILLA-MALDONADO, Daniel Eduardo. La Arquitectura Conceptual del Principio de Separación de Poderes. Vniversitas, [s.l.], n. 131, p. 231-276, 2015. p. 238.
} 
The procedural aspect of the Rule of Law is a thinking about Law that emphasizes arguments in judgments 17 as well as the existence and recognition of rules as the basis, opposing the understanding of values or principles as basis of the Rule of Law existing in contemporary political arguments. The Separation of Powers is "concerned with regulating 'who' exercises this or that function, nevertheless puts special emphasis on strengthening the 'how'. In the 'forms' of the exercise of functions or powers is where the epicenter of the constitutional state" 18 .

In this sense, it is maintained here that the Rule of Law does not only refer to general rules and principles; but rather on the impartial administration and judgment of these through an identifiable due process. The violation of this occurs when the institutions that should incorporate these procedural safeguards are impaired to carry them out or prevented from doing them in a free way. In this way, the Rule of Law becomes directly associated with political ideals such as the Separation of Powers and the independence of the judiciary, to theoretically guarantee these judgments.

It is not positive that there are clear and general rules if they are not properly administered; And it is not good to have fair procedures if the rules, whose applications are in question, undergo constant changes, if they are eventually ignored or lack a plurality of possible interpretations. Therefore, the Rule of Law is an ideal designed to correct the dangers of abuse that occur in general when political power is exercised, and not dangers of abuse occurring in a particular law. Thus, the Rule of Law seeks to correct abuses of power by insisting on a particular way of exercising political power in this case, governance through Law.

The contrast between the Law and the arbitrary exercise of power has to do with institutions and its procedures, which are established with the help of the Separation of Powers. These institutions should do the judgments through formal events - these being the hearings - for which there must be a rigorous procedural framework to make these procedures a skillful mean of saying the rights, impartially, fairly and effectively after the arguments and evidence of both sides are heard. There is a remarkable tendency of philosophical views to see the Law simply as a set of normative propositions which setting forth ideal propositions would suffice.

However, what is proposed here is that Law comes to life through institutions. Thus, when thinking about the Rule of Law as a procedure, we bring a conceptual thinking of Law into social reality. Lon Fullers conception ${ }^{19}$ becomes associable at

\footnotetext{
17 It should be noted here that when referring to judgment in this part, we think of judgments in a lato sensu, not only the judgments that are exercised by the Judiciary, but also all kinds of judgments in the Executive and Legislative branches.

18 CORVALÁN, Juan G. Los ejes centrales de la división de poderes en el Estado Constitucional de Derecho. Revista de Investigações Constitucionais, Curitiba, vol. 2, n. 1, p. 225-256, jan./abr. 2015. DOI: http://dx.doi.org/10.5380/rinc.v2i1.43661. p. 251.

19 In his theory, Fuller establishes eight "principles for legality", in which he maintains that the necessary characteristics are an "internal morality". He states that these essential conditions must be present to some degree in a legal system, and the essence of this "duty" is moral.
} 
this point, since it is suggested that the concept of Law involves the fundamental elements of legality, however, arguing that legality must also place a place on procedural importance and its respective institutional elements. But the procedural character stands out, since, for example, the judges display a way of proceeding that offers those directly involved in a dispute the possibility of the parties submitting and presenting evidence, according to strict procedural rules, which may assist in the application of the rule in question.

Even if the way in which this evidence are presented may vary according to the legal system analyzed, the existence of this possibility is something inherent to the Rule of Law, which is a characteristic of the due process. Law is a form of social governance that treats individuals with reasonable respect 20 , at the time when citizens can create individual perspectives in the present regarding the future application of the rules that condition their actions and situations21. Applying the rule to the human being is not just like deciding what to do with objects, it involves a special attention to the different points of view and respect for the personality of the individual with whom one is dealing. In this way, it encompasses a crucial idea of dignity - by respecting the dignity of those who are affected by rules as beings capable of constructing and arguing their position before the Law.

Theorizing about the formal aspects of the Rule of Law is often only a way of getting to the procedural aspects of the Rule of Law, which is what litigants really care about, the norm applied in the way it affects the social environment. Making the distinction clear, the theorizing here set forth does not simply involve that the proper judges are bound to apply the given rules while other groups would not be. It is that judges work under the context of more proceduralized institutions; in which the rights and duties of all kinds allow the application of determined rules to be established in a fair and meticulous manner with ample opportunity of challenge on a case-by-case basis.

In the legal systems that we are familiar with, Law presents itself as something that "makes sense". The norms that are administered in a legal order may appear to be just one command after another for the average citizen. However, for the different operators of the Law there is an attempt to see the Law as a whole; trying to discern some kind of coherence or system through ordinary rules, integrating specific items in a structure that gives better flow to the total sense of the rules when integrated with

\footnotetext{
20 At this point, it is important to mention Axel Honneth recognition theory. In his theory one of the forms of struggle for recognition happens in what he calls the legal sphere, in this sphere, individuals would construct a vision of themselves and others as holders of rights and obligations. Thus, for the author this conflict in the legal relationship is based on universal moral principles, treating all subjects in an egalitarian way. Thus, subjects have the security of being able to share with all the collective the properties that enable them to participate in a discursive formation of the will. For further reading on the subject see, HONNETH, Axel. The Struggle for Recognition: The Moral Grammar of Social Conflicts. Cambridge: The MIT Press, 1996.

21 It is interesting to mention the classic work about the creation of rational expectations of agents in the economic market, which can serve to better understand how individuals create expectations before the norms, MUTH, John. Rational Expectations and the Theory of Price Movements. Econometrica, [s.I.], v. 29, p. 315-335, 1961.
} 
each other. Thus, a model of Rule of Law requires that a society governed by it, see more relevance if its legal procedures do not give the parties the opportunity to present arguments in their cases than what the Rule of Law as substance or mere formality represents.

Communicating with the principle of Separation of Powers again, the Rule of Law is violated when rules that are applied by legal operators do not correspond to the rules that have been made public to the citizens, or when government agents act on their own criteria, rather than previously established rules. If such an action becomes endemic, then not only people's expectations are getting frustrated, but increasingly citizens will find themselves unable to form expectations in which to rely under the legality of the state; And the horizons of planning and economic activities would shrink accordingly. It is therefore natural to think that the Rule of Law must counterbalance the uncertainty arising from the argumentative character of the Law itself.

But it is also important what we do of the Law with the rules that have already been deliberated and introduced under the expectation of the citizens. One should not only obey them or apply the sanctions that constitute them; But rather to give due respect and observance to how these rules open space for adversarial argumentation, using a notion of what is at stake in the actual application, to license a continuous process of argument between the parties, exercising an elaborate debate on the meaning of applying a rule. Thinking how it possible for such interpretation to constitute a systematic meaning for the cases that came before us, also aiding those that might be coming down the road.

When thinking about judgments, hearings and arguments it should be made clear that: these are inherent aspects of the Law, not options to those who judge or execute the Law to carry out if it seems convenient. Thus, they are integral parts of how the Law works; and are indispensable as a "package" of respect for the right to human action. We should value those aspects of governance that promote the clarity and determination of rules that aim at individual freedoms, which are necessary for the free exercise of these procedures, especially the one of having a voice before the state, being able to argue and participate in both the social environment and in the legal and deliberative environment.

\section{PROBLEMS WITH THE IDEALIZATION AND THE SEPARATION OF POWERS IN THE BRAZILIAN STATE}

First of all, it is important to clarify why we treated such conception of the Separation of Powers as idealized. And the answer for such a question is rather simple: it perceives the Separation of Powers in thought, but hardly in practice. Or at least, the meanings of practice proposed here and Waldrons account, for example, are semantically 
different. By overlooking the practical problems that already exist - and have been around for some time - such conception can only be treated as idealized, for it is even possible to think of it as "the rigid version of the separation of powers that determines the exclusivity in the distribution of functions. This radical formulation has not been applied strictly in practice"22. By no means this paper tries to diminish such conception, we're only implying that in practice, the tendency is a necessity to move away from the ideal - and rigid - form of the Separation of Powers, to adequately respond the existing clashes between the powers. But it is also important to highlight that in order to improve something, we first must comprehend it. The idealization brings a "genuine set of concerns and warns against a certain oversimplification of governance".23

The principle of Separation of Powers is a political principle linked to constitutionalism, it is presented to some extent in all states that "are democracies and recognize basic rights" 24 . The Separation of Powers does not arise from constitutionalism itself, it does not even require a legal provision in constitution for its existence, "as a result, even the question of whether the concept should be understood as a legal rule or a political mechanism remains open"25. But, the focus presented here is that the Separation of Powers is a political choice of society, just as constitutionalism is. Even so, the Brazilian constituent opted 26 for expressly positivate the principle of Separation of Powers in the Constitution, especially in article 2, by mentioning that "they are independent and harmonious Powers of the Union, Legislative, Executive and Judiciary" and when it chooses the "Separation of Powers" as a hard clause or entrenchment clause in its article 60. One of the main problems for the Separation of Powers revolves around constitutional interpretation, since it's a concurring competence.

Hence the question about the institutional order in the Brazilian Rule of Law: there is a growing tendency to increase the institutional capacity of the judiciary in detriment of other powers by the exercise of the constitutional interpretation through the jurisdiction. The thought revolves around the idea that the judiciary"allows to reconcile

22 CORVALÁN, Juan G. Los ejes centrales de la división de poderes en el Estado Constitucional de Derecho. Revista de Investigações Constitucionais, Curitiba, vol. 2, n. 1, p. 225-256, jan./abr. 2015. DOl: http://dx.doi.org/10.5380/rinc.v2i1.43661.p. 229.

23 WALDRON, Jeremy. Political Political Theory: Essays on Institutions. Cambridge: Harvard University Press, 2016. p. 71.

24 MÖELLERS, Christoph. The Three Branches: A Comparative Model of Separation of Powers. Cambridge: Oxford University Press, 2013. p. 50.

25 MÖELLERS, Christoph. The Three Branches: A Comparative Model of Separation of Powers. Cambridge: Oxford University Press, 2013. p. 50.

26 A opposition exists that although the Principle of Separation of Powers is a political choice of society, there is no guarantee that this political choice is respected by the constituents (parliamentarians). For this critique is taken from the work of KELSEN, Hans. A democracia. Trad. Ivone Castilho Benedetti, Jefferson Luiz Camargo, Marcelo Brandão Cipolla, Veraa Barkow. 2 ed. São Paulo: Martins Fontes, 2000. Thus, it is hypothesized that the political principles chosen in a representative democracy do not depart from the unity of the people, but rather from an indirect and parliamentary form, in which the general will is not formed by the union of several individual wills - or by a metaphysical will - but by the majority among those who were elected to parliament. Thus, the choice of the political principles of a society does not happen in a consensual way by the people, but rather by a procedure of clash between the members of parliament, which, in Kelsen's conception, end up searching the middle way between opposing interests. That is, the principle of the separation of powers can be said to be a choice that results from the conflict between various antagonistic social forces. 
the constitutional obligation to transform positive rights into concrete reality, without disrespecting the authority of the Legislative and Executive"27. But also, the judiciary has been giving its own assessment of what has been done by the executive and the legislature, reviewing their actions almost "from above".

This is a competence derived from the Separation of Powers that should be exercised with great institutional caution, for it may hurt the Separation of Powers itself; Although it is seemingly becoming a more common practice. The Federal Constitution, when treating the Federal Supreme Court as guardian of the Constitution, limits the constitutional debate between the three powers, even putting judicial decisions on top of legislative deliberations or administrative discretion. Such a scenario has made an "institutional rise of the Judiciary and, especially, of the Federal Supreme Court"28.

Although this competence may have its historical importance in order to guarantee a good democratic progress, it must be questioned whether in a plural society and a consolidated democracy such as the Brazilian one, this institutional role must be maintained. This conflict between powers can be seen as a conflict of competences in practice. Taking into account this scenario of possible "judicial governance" is that a proposal of dialogue will be presented further in this paper, for a flexibilization of the constant use of jurisdiction for the solution of social problems 29.

In some opportunities, the Brazilian legislator adopted different interpretations of the constitutional court causing a direct clash, such as in the cases of municipal public lighting and collection of social security contributions from inactive servers; This was done through constitutional amendments, which goes far beyond what the principle of the Separation of Powers provided so far delimits in its idealized state. Such conflict does not seem to be productive at all, but merely a struggle on both sides to decide who has the final word on a matter. It takes a sensitivity, that is still to be developed, of the different powers to know how to work with their decisions without making the government that composes the State into an "environment of war". This brings a need for recognition of diverse competencies and that all decision-making authorities must have a degree of autonomy to do decide when needed.

The problem that is posed - and not solved in order to not escape the object - is that there are constitutional mechanisms that give some level of judicial control of the public administration that configure intervention and affect the integrity of action of

\footnotetext{
27 KLATT, Matthias. Direitos a prestações positivas: quem deve decidir? Controle judicial ponderado. In: ALEXY, Robert; BAEZ, Narciso Leandro Xavier; SILVA, Rogério Luiz Nery da (org.). Dignidade humana, direitos sociais e não-positivismo inclusivo. Trad. Carlos Luiz Strapazzon. Florianópolis, 2015. p 237.

28 CAMPOS, Carlos Alexandre de Azevedo. Dimensões do Ativismo no STF. Rio de Janeiro: Forense, 2014. p. 19.

29 Contrary to such belief it is possible to cite MEYER-PFLUG Samantha Ribeiro; CAMARGO, M. L. M. S.. O ativismo judicial e a tripartição de poderes. E-CIVITAS, v. IX, p. 153-174, 2016. This work implies that there would be no problem with the use of the constitutional jurisdiction, for the power is only one and there is only division of functions. However, the work does seem to fail to address the possibility of a "judicial governance".
} 
each of the powers, since they modify and review positions taken by other powers, and so it is a matter of constitutional design. It is potentially favorable to see the scale of the interference and its form (as to substantiality or formalities), since it may be possible for one action to remain free from contamination of another power, even though it has been appreciated by it. Although the theoretical possibility here is raised, the scenarios of the hypothesis of non-contamination can be difficult to prove in practice, but it opens the possibility for case studies.

\section{EXEMPLIFING A PRACTICAL PROBLEM: THE CLASH OVER THE CASE OF THE "VAQUEJADA"}

A current example of the difficulty in preserving the principle of the Separation of Powers is the dispute between the Supreme Court and the Congress, specifically on the theme vaquejada, a cultural event in northwest of Brazil, in which two mounted cowboys take down an ox. It's well-known that in the remote moment of its creation as in the current days the vaquejada is guided by the same end, that is, to overthrow the ox pulling it by the tail, leaving it with the four legs facing upwards. However, it is denoted that the techniques have been improved, such as the ox's confinement in a narrow corridor before the arena, where the ox will be released to be overthrown by the cowboys. On this occasion, the animals are whipped, physically and psychically abused, aiming to achieve their emotional imbalance 30 .

The main discussion began when the state of Ceará published the law $15.299 / 2013$ to regulate the events related to this practice, establishing the vaquejada as a sporting and cultural activity31. On the other hand, in the same year, the Republic's General Attorney Office $(P G R)$ lodged a Direct Unconstitutionality Action $(A D I)$ in the Federal Supreme Court with the intention to declare the unconstitutionality of this state law. The cause of action in this case is directly related to the regulation of an activity that necessarily involves cruelty to animals (considering the environment as a universal right), and furthermore, that the proven cruelty against the animals does not find a constitutional protection in Brazil, even if inserted in a specific cultural context.

For the defenders of the vaquejada, one of the main arguments is based on the local folklore. In the places where these events occur, the regional cultural identity remain constituted by symbols of a static memory, based today by imaginary histories of bravery, courage and sagacity of the old cowboys passed on to the new cowboys ${ }^{32}$.

\footnotetext{
30 GORDILHO, Heron José de Santana; FIGUEIREDO, Francisco José Garcia. A vaquejada à luz da Constituição Federal. Revista de Biodireito e Direito dos Animais, Curitiba, v. 2, n. 2, p. 78-96, Jul./Dez. 2016. p. 83

31 CEARÁ. Lei n. 15.299/2013. Regulamenta a vaquejada como prática desportiva e cultural no Estado do Ceará. Diário Oficial do Estado, Poder Executivo, Ceará, 8 jan. 2013.

32 SIQUEIRA FILHO, Valdemar; LEITE, Rodrigo de Almeida; LIMA, Victor Breno de. A prática da vaquejada em xeque: considerações sobre a ação direta de inconstitucionalidade n 4.983. Revista Brasileira de Direito Animal, Salvador, v. 10, n. 20, p. 59-80,
} 
Moreover, those who defend the practice of the vaquejada, justify their reasons using as an argument the economic scenario. The vaquejada instigate the local economy, as well increasing the employment rates, and therefore, the income of the population of these regions. It is also important to keep in mind that in 2001, with the consolidation of some sports rules, the cowboy figure started to be considered a professional athlete ${ }^{33}$.

In other words, the action placed face to face the right to free cultural expression (article 215 of the Constitution) and the right to an ecologically balanced environment, free from animals' cruelty (article 225 of the Constitution). The Constitution, concurrently, grants the right to culture and the environment. Revealing, in this way, the inexistence of a hierarchy between these two fundamental rights. In this step, both articles 215 as 225 of the Federal Constitution must be handled by the interpreter of the rule or the court. Thus, on the particular case when these fundamental rights enter in an apparent collision course, it is necessary for the interpreter to use the technique of weighting the rights to define which one of them should prevail in that factual situation ${ }^{34}$.

Before the Supreme Court's decision, Brazilian studies already brought the idea that the Ceará's state law no 15.299/2013 suffers from a material defect, it is unconstitutional. The law contradict the constitutional prohibition expressed in article 225 (mistreatment of animals), it legitimizes a sport which causes suffering to animals, besides that, the very purpose of vaquejada constitutes in cruelty to animals. Thus, the referred law goes against the Federal Constitution 35 . It must be emphasized that, in order to regulate the provisions of article 225, $\$ 1$, VII of the Federal Constitution, the Congress established a series of acts that will be considered environmental crimes (law no. 9605/98), including the crime of mistreatment against animals, which, according to article 32 of this law, consists in practicing an act of abuse, mistreatment, injury or mutilation of wild, domestic or domesticated animals, native or exotic ${ }^{36}$.

The competitors, sympathizers and communities involved in the vaquejada have, prima facie, the right to have guaranteed by the State the full exercise of their cultural rights, as well the support and incentive for the valorization and the diffusion of their cultural manifestations. On the other hand, the community has, prima facie, the right of protection of the environment according to the express prohibition in the Federal Constitution of any act that subjects animals to ill-treatment. The judgment

set./dez. 2015. p. 64-65.

33 BRASIL, Lei n. 10.220/2001. Institui normas gerais relativas à atividade de peão de rodeio, equiparando-o a atleta profissional. Diário Oficial da União, Poder Executivo, Brasília, 12 abr. 2001.

34 GORDILHO, Heron José de Santana; FIGUEIREDO, Francisco José Garcia. A vaquejada à luz da Constituição Federal. Revista de Biodireito e Direito dos Animais, Curitiba, v. 2, n. 2, p. 78-96, Jul./Dez. 2016. p. 91.

35 BRITO, Renan Moreira de Norões. Lei 15.299 de 2013/CE: consagração do direito fundamental à liberdade de manifestação cultural ou legitimação dos maus tratos contra animais?. Planeta Amazônia: Revista Internacional de Direito Ambiental e Políticas Públicas, Macapá, n. 6, p. 69-83, 2014.

36 BRASIL, Lei $\mathbf{n}^{\circ} \mathbf{9 . 6 0 5}$, de 12 de fevereiro de 1998. Dispõe sobre as sanções penais e administrativas derivadas de condutas e atividades lesivas ao meio ambiente, e dá outras providências. 
here is attached to the interest of the collectivity, without discussion into the merit of animal sensuousness, although this argument has extreme relevance in an analysis of the prohibition of animal's abuse. In this case, the principle of the full exercise of cultural events strongly limits the legal viability of the principle of protection of the environment and prohibition of ill-treatment ${ }^{37}$.

In the decision of $A D / 4.983$, the justice Marco Aurélio explained that the behavior of the Supreme Court in cases in which it was necessary to consider the right to the environment against individual rights, the collective interest has prevailed 38 . In addition, the justice based his vote in the empirical data evidenced by researches, thus, it is considered as indisputable the cruel treatment given to the animal species involved 39 . More detailed was the vote of justice Barroso, he pointed out that the Constitution has advanced in the field of animal ethics, being one of the few in the world to expressly prohibit animal's cruelty.

According the justice Barroso, the right to the environment does not condition this protection of animals, although inserted in article 225. Firstly, this clause prohibiting animal cruelty was inserted in the Constitution, based on the discussion in the constituent assembly about cruel practices against animals, especially the event called farra do boi, and not as a measure aimed at ensuring an environmentally balanced environment. Secondly, if the purpose of the constituent were just ecological, it would not be necessary to include the prohibition of cruelty practices against animals in the wording of art. $225, \S 1$, VII, since, in the same device, there is a duty to protect the fauna, and, it was also not for a preservationist purpose, since there is in the same provision a clause prohibiting practices that provoke the extinction of species 40 .

Then, the prohibition of cruelty to animals in the Constitution must be considered as an autonomous rule, so that their protection is not only due to an ecological or preservationist function, but in order that animals are not reduced to the mere condition of objects. The justice remembered that none of the animal related practices analyzed by the Supreme Court, alone, could destabilize the environment, jeopardize the ecological function of the fauna or cause species extinction. All of these practices, however, subjected the animals involved to cruelty and, for that sole reason, were declared incompatible with the Constitution 41.

\footnotetext{
37 GRUBBA, Leilane Serratine; CADORE, Caroline Bresolin Maia. Proteção ao meio ambiente, aos animais e o direito à cultura: a aplicação da fórmula do peso refinada de Robert Alexy. Revista Brasileira de Direito Animal. Salvador, v.12, n. 02, p. 193-219, mai./ago. 2017. p. 212

38 BRASIL. Supremo Tribunal Federal. ADIN n 4.983. Requerente: Procurador-Geral da República. Requeridos: Governador do Estado do Ceará e Assembleia Legislativa do Estado do Ceará. Relator: Min. Marco Aurélio, p. 3

39 BRASIL. Supremo Tribunal Federal. ADIN n 4.983. Requerente: Procurador-Geral da República. Requeridos: Governador do Estado do Ceará e Assembleia Legislativa do Estado do Ceará. Relator: Min. Marco Aurélio, p. 5

40 BRASIL. Supremo Tribunal Federal. ADIN no 4.983. Requerente: Procurador-Geral da República. Requeridos: Governador do Estado do Ceará e Assembleia Legislativa do Estado do Ceará. Relator: Min. Marco Aurélio, p. 41-42.

41 BRASIL. Supremo Tribunal Federal. ADIN n 4.983. Requerente: Procurador-Geral da República. Requeridos: Governador do
} 
The Supreme Court had already appeared in cases involving the collision between the protection of cultural manifestations and the restriction of cruelty against animals, before the $A D I$ 4.983. In the Extraordinary Appeal 153.531, it was discussed the cultural manifestation, called "farra do boi", by majority vote, the Second Panel understood that this practice is unconstitutional. In the $A D I 1.856$ and 2.514, the Court took similar decisions on whether the competitions known as "rinha de galo". In both cases the solution adopted was the prevalence of the preservation of the environment' constitutional rule, followed by imposition of legal limits on cultural manifestations. Thus, the vaquejada case was not the first time the Supreme Court judged in the sense of harmonizing the public liberties to resolve specific conflicts between cultural manifestations and protection to the environment.

The analysis of $A D I \mathrm{n}^{\circ}$. $1.856 / \mathrm{RJ}$ of $2011, A D I \mathrm{n}^{\circ}$. 2.514/SC of 2005, related to the practice of "rinha de galo" and "farra do boi", respectively, both hold their declared unconstitutionality, in the sense that the solution adopted in these precedents is by the prevalence of the constitutional rule of preservation of the environment and corresponding imposition of legal limits on cultural manifestations, a circumstance in which the submission of mistreatment and cruelty to animals must be observed. Thus, it is not new for the Federal Supreme Court to manifestate itself in the sense of harmonizing public liberties to resolve specific conflicts between cultural manifestations and protection of the environment, with the predominance of avoiding practices of inadequate treatment of animals, even within contexts cultural and sports, notwithstanding the fact that it is also a parameter of constitutional protection.

It is visible that, the activities already declared unconstitutional by this Court are cultural manifestations with characteristics of entertainment and not of another nature, as, for example, religious. On the other hand, the vaquejada also possesses entertainment characteristics, since it is a recreational-competitive activity, with characteristics of sport. Indeed, according to the character of the practices analyzed by the Court and in the need to keep the interests housed in the constitutional rules in collision, justice Barroso considered more appropriate balancing between them and state that "cultural manifestations with entertainment characteristics that subject animals to cruelty are incompatible with the Constitution, when its regulation is impossible to avoid cruel practices, without the practice itself being de-characterized" 42 . Thus, for six judges, the majority of the court, animal suffering is intrinsic to vaquejada.

However, justice Edson Fachin and other four justices voted on the sense to preserve what was considered Nordeste's cultural heritage. For justice Fachin, the case needs to be analyzed with a view that reaches the reality of the rural population. It is

Estado do Ceará e Assembleia Legislativa do Estado do Ceará. Relator: Min. Marco Aurélio, p. 42.

42 BRASIL. Supremo Tribunal Federal. ADIN n 4.983. Requerente: Procurador-Geral da República. Requeridos: Governador do Estado do Ceará e Assembleia Legislativa do Estado do Ceará. Relator: Min. Marco Aurélio, p. 46. 
necessary to put aside a unilateral vision of an urban society. On the contrary, the vaquejada constitutes a way of creating, doing and living of the sertanejo, justice Fachin used these expressions "create, do and live", because they are found in the exact terms of section II of article 216 of the Constitution ${ }^{43}$. Thus, for the minority of the Supreme Court, the right to cultural manifestation must be protected, as long as it may exist vaquejada without animal suffering (or with a minimum suffering).

Thus, in the case of vaquejada, within the interpretation of the Supreme Court, the consideration is that the principle of protection of cultural manifestations has less concrete weight than the principle of protection to the environment (animals). It demonstrates, then, a link of primacy in the concrete case of the principle of protection to the environment over the principle of protection of cultural manifestations 44 .

It is possible to affirm that the decision of the Supreme Court that considers the preservation of animal dignity against any cruel cultural/sportive practice should link the whole country's judiciary, developing a new vision of animal dignity and, extirpating the idea of anthropocentrism. Likewise, the duty to preserve animal dignity arises in the Public Administration, giving it the opportunity to concretize the preservation of the environment and to combat cruel cultural practices to animals. Consequently, the result expressed in the $A D I 4.983$ constitutes true landmark of the breakdown of paradigms in the form of looking at animal law, this means, outside the human egocentrism, traditionally turned to the belief that humans are radically different from all other animals 45 .

However, it is important to point out that, in the first day of November 2016, less than a month after the Supreme Court decided the ADI 4.983, the Senate approved the House's Bill no. 24/2016, written by Deputy Captain Augusto (PR-SP), which elevates the rodeo (rodeio) and vaquejada to the status of national cultural manifestation and intangible cultural heritage. The project was sanctioned and entered into force on November 29, 2016 as law n. 13.364. Anyhow, the federal law, on its own, had no practical effect, given the repercussion of the Supreme Court judgment. Nevertheless, this movement of the Congress already denotes a diverging position between the Congress and the Court.

On June 6, 2017, Congress promulgates Constitutional Amendment 96 (EC) which adds paragraph 7 to article 225 of the Constitution. This article states that sporting practices that use animals are not considered cruel under the following conditions:

\footnotetext{
43 BRASIL. Supremo Tribunal Federal. ADIN n 4.983. Requerente: Procurador-Geral da República. Requeridos: Governador do Estado do Ceará e Assembleia Legislativa do Estado do Ceará. Relator: Min. Marco Aurélio, p. 15.

44 GRUBBA, Leilane Serratine; CADORE, Caroline Bresolin Maia. Proteção ao meio ambiente, aos animais e o direito à cultura: a aplicação da fórmula do peso refinada de Robert Alexy. Revista Brasileira de Direito Animal. Salvador, v.12, n. 02, p. 193-219, mai./ago. 2017. p. 216

45 SILVA, Tagore Trajano de Almeida; VIEIRA, Laira Correia de Andrade. A inconstitucionalidade da vaquejada: uma análise da dignidade animal sobre a ADI nº. 4983 e a lei estadual nº. 15.299/13. AREL FAAR, Ariquemes, v. 4, n. 3, p. 42-60, set. 2016. p. 44
} 
For the purposes of the final part of item VII of $\S 1^{\circ}$ of this article, sporting practices that use animals are not considered cruel, as long as they are cultural manifestations, according to $\S 1^{\circ}$ of article 215 of this Federal Constitution, recorded as an intangible asset that is part of the Brazilian cultural heritage, and must be regulated by a specific law that ensures the welfare of the animals involved 46 .

This proposed amendment, which had an accelerated procedure both in the Senate and in the Chamber of Deputies, had its rite questioned in the Supreme Court in a writ of mandamus. The petitioner, Dep. Marcelo Henrique Teixeira Dias (PR-MG) argued that by including the proposed Constitutional Amendment - PEC 304/2017 (called vaquejada amendment) on the agenda and not being aware of the point of order formulated by him, the authority violated its certain right to participate in a legislative process, violating constitutional, legal and regimental norms. Also, the deputy pointed out that the Federal Senate had not observed a minimum period of five days between the two rounds of voting in that House, since both votes were on February 14, 2017, with only half an hour between one and another poll.

However, Justice Ricardo Lewandowski dismissed the writ of mandamus as impracticable because he understood that it was not the role of the judiciary to intervene in an internal matter of the Congress. In his vote, the Justice affirms that it is important to state in the merit of this warrant that in the republican regime there is a horizontal sharing of power between the Legislative, the Executive and the Judiciary, for they are independent and harmonious among themselves (Article 2 of the Constitution). Based on this basic constitutional rule, the guidance of the Supreme Court is solid in the sense that issues pertaining to the interpretation of regimental rules of the Congress are of internal nature, which are beyond judicial review.

In this way, it was not possible for the mandamus to advance and even discuss if, by giving a special procedure to the amendment, the parliamentarians applied well or badly the regimental rules. In addition, he pointed out that the Supreme Court's had already established that the Constitution does not establish the interval between voting rounds in the procedure of amendment to the Constitution. For all these reasons, Justice Lewandowski extinguished the action based on the previous decisions of the Supreme Court on the fundamental issue, which prevents its interference in the strictly domestic sphere of the Congress 47 .

This amendment can be understood as an attempt of the Congress to overcome the Court (reversal of constitutional interpretation), a manifestation of congressional

46 BRASIL. Constituição da República Federativa do Brasil de 1988.

47 BRASIL. Supremo Tribunal Federal. MS 34802 MC. Impetrante: Marcelo Henrique Teixeira Dias. Impetrado: Presidente da Câmara dos Deputados. Relator: Min. Ricardo Lewandowski. 
activism. The EC 96/2017 is an example of what constitutionalist doctrine calls the backlash effect. In very simple words, backlash effect consists in a conservative reaction of part of the society or, in this particular case, of the political forces (Congress) after a liberal decision of the Court in a controversial issue.

The negative side of the backslash effect occurs as a process that can be explained as it follows. In a matter that divides public opinion, the Judiciary makes a liberal decision, taking a vanguard position in the defense of fundamental rights, in the specific case of animal rights. As the social conscience is still not well consolidated, the judicial decision creates a tension with the conservative speeches ${ }^{48}$. The criticism of the judicial decision entails a change in public opinion, capable of influencing the electoral choices of a large part of the population ${ }^{49}$. With this, the candidates who adhere to the conservative speech usually conquer more political space. The conservative political group now is able to pass laws and other measures that match its view of the world50. As the political power also influences the composition of the Judiciary, since the members of the Supreme Court of are indicated politically, it opens a space for change of understanding within the very judicial power. After all, there could be a legal setback that could create a normative situation even worse than the one that existed before the court decision, harming the groups that were supposed to benefit from that decision 5152 .

Finally, this amendment is also being discussed in an ADI, filed on June 13, 2017, by the National Forum for Protection and Animal Defense. In this action, the organization claims that the amendment $96 / 2017$ supressed the core of the right to a balanced environment, since it affects in the prohibition on the submission of animals to cruel treatment. The organization also claim that the rule also offends the Article 60 (paragraph 4, item IV), according to which the proposal would characterize an amendment that abolishes an hard clauses, among which the fundamental right to animals is situated. Decision of the Supreme Court that found unconstitutional laws on vaquejada was cited as important precedent on the subject, because the Court considered these activity intrinsically violent and cruel to animals. The National Forum for Protection and Animal Defense calls for an order to suspend the effectiveness of the rule, and, on merit, that

\footnotetext{
48 KLARMAN, Michael. How Brown changed race relations: the backlash thesis. The Journal of American History, v. 81, n. 1, p. 81-118, 1994.

49 KLARMAN, Michael. Courts, Social Change, and Political Backlash. In: Hart Lecture at Georgetown Law Center, 31 Mar. 2011. Speaker's Notes.

50 POST, Robert; SIEGEL, Reva. Roe Rage: democratic constitutionalism and backlash. Harvard Civil Rights-Civil Liberties Law Review, v. 42, p. 373-433, 2007.

51 SIEGEL, Reva. Same-sex marriage and backlash: constitutionalism through the lens of consensus and conflict. Max Weber Lecture, n. 04, 2016.

52 BUNCHAFT, Maria Eugenia; LIMBERGER, Têmis; CRISTIANETTI, Jessica. O refluxo em Roe versus Wade: uma reflexão à luz do diálogo entre constitucionalismo democrático e minimalismo judicial. Pensar - Revista de Ciências Jurídicas, v. 21, n. 3, p. 987-1011, set./dez. 2016.
} 
the Court declares the unconstitutionality of the amendment. The case is under the responsability of Justice Dias Toffoli, who applied the abbreviated procedure of article 12 of Law 9.868/99 to the case, so that the decision can be made definitively, without preliminary examination of injunction, due to the relevance of the matter 53 .

\section{POSSIBILITY TO OVERCOME THE PROBLEMS AND LIMITATIONS}

The role of courts under the Separation of Powers in its idealized version should be limited to determining whether an action of one of the powers is under its competences derived from the Constitution, if it is outside its competence, then there would be unconstitutionality and need for review by the other powers - contrary to some existing constitutional aspects, for example, the Brazilian Constitution gives far too much power to the Judiciary as a guardian to exercise the judicial review. But at the same time, if it was otherwise, a possible contradiction would appear: if the legislature overcomes a decision of the Supreme Court, that is a mean of constraining the power of the judiciary in its exercise. Such complex problem still has no sufficing answer.

The proposal here defended that seems to provide the most adequate answer is of constitutional dialogue. It's not completely new, or free of problems, but it is a way of seeing the constitutional process that does not believe in a final word, for there is nothing to prevent the other powers from responding to a previous decision. Thinking in terms of dialogue makes it possible for a continuity of the political debate, while also maintaining a circularity of the Separation of Powers "that only terminates or stabilizes when it reaches a minimal agreement, even if it is provisional"54. And as the Rule of Law is made of procedures and safeguards, it is possible to avoid oscillations, revisions, or constant mutations while still being open to debate.

But how is it possible to walk towards a Separation of Powers that is not simply adversarial? Firstly, the Judiciary assumes the role of acting as only one of the forums for discussion, allowing society to achieve the conception it deems most appropriate. The meaning of the constitution is to be given not only by the powers, but by the people themselves, in an integrated dialogue. For such possibility, a dialogic theory that fuses Equilibrium and Partnership is presented. The Equilibrium theory of dialogue is a theory that views a way of "fostering society-wide constitutional discussion that ultimately leads to a settled equilibrium about constitutional meaning" 55 . Even more, such

\footnotetext{
53 BRASIL. Supremo Tribunal Federal. ADIN n 5728. Requerente: Fórum Nacional de Proteção e Defesa Animal. Requeridos: Mesa da Câmara dos Deputados e Mesa do Senado Federal. Relator: Min: Dias Toffoli.

54 MENDES, Conrado Hübner. Not The Last Word, but Dialogue: Deliberative Separation of Powers II. Legisprudence, [s.I.], v. 3, n. 2, p. 191-246, 2009. p. 216.

55 BATEUP, Christine. The Dialogic Promise: Assessingthe normative potential of theories of the constitucional dialogue. New York University Public Law and Legal Theory Workin Papers, New York, p. 1-85, 2005. p. 57.
} 
dialogue is an open door for "the possibility of self-revision and transformation over time as the nation's self-understanding grows and changes" 56 .

Such equilibrium must communicate with a Partnership Theory in order to be more complete, the belief is that institutional dialogue should be created in society, and institutional mechanisms are seen as the best way to strengthen and provide institutional dialogue. As a result, the Judiciary, because of its direct political isolation, is entrusted with recognizing the situations limiting fundamental rights, while the legislative formulates policies, making the way possible for the dialogue to strengthen the protection of fundamental rights; "The partnership model of dialogue centers on the recognition that the differently situated branches of government can make distinct contributions to constitutional dialogue in a way that does not privilege the judicial role" 57 . The fusion between equilibrium and partnership enables a reconciliation of democratic concerns and institutional ones.

The institutional dialogue involves a permanent action of reciprocal provocations, whose objective is the improvement of the effectiveness of the Constitution. So it is possible to flexibilize the constitutional jurisdiction by accepting that there is some political dimension on the judicial review, even though not in the traditional form of politics. Such dimension explicitly overcomes the judiciary as only technical and the myth of its neutrality, for it has a role in political questions. What matters is the design we give to such a role, finding ways to adequately limit it.

It is necessary, in addition to a less activist stance on the part of the constitutional court, a commitment of the other political actors to participate in the prescribed form of procedures, instead of simply submitting to the judicial decisions, distancing from legislative inertia and the interest in transferring to the judiciary the burden of deciding on certain socially relevant issues. What is important is the manifestation of the most varied subjects, who must use the procedures inherent to the Rule of Law to have a political and legal voice, including the different powers. As such, we also believe that "the ratio of the separation of powers in democratic constitutional states is not the repression and facilitation of political power, but rather the organization of a model of law-making in which individual and democratic matters of self-determination gain equal recognition"58

There are already some steps towards such dialogue in Brazil59, but it is facing ups and downs more than we would like. And if we simply understand dialogue as

\footnotetext{
56 BATEUP, Christine. The Dialogic Promise: Assessingthe normative potential of theories of the constitucional dialogue. New York University Public Law and Legal Theory Workin Papers, New York, p. 1-85, 2005. p. 66.

57 BATEUP, Christine. The Dialogic Promise: Assessingthe normative potential of theories of the constitucional dialogue. New York University Public Law and Legal Theory Workin Papers, New York, p. 1-85, 2005. p. 70.

58 MÖELLERS, Christoph. The Three Branches: A Comparative Model of Separation of Powers. Cambridge: Oxford University Press, 2013. p. 109.

59 VALLE, Vanice Regina Lírio do. Dialogical constitutionalism manifestations in the Brazilian judicial review. Revista de Investi-
} 
"in that ongoing (and apparently, never-ending) enterprise of revealing and updating constitutional meaning" 60 , too many conflicts between the powers can be dialogue, even those who are mere power struggles, and no minimal provision settled, which is the goal of dialogue. The concept for what constitutes dialogue between the powers still needs to be more precised in order to be truly operational. Although Garcia makes a statement with the constitutionalism of latin american in mind, the diagnostics is the same, that "The principle of 'separation of powers' is always alive and still forms the foundation of our democratic societies"61. Therefore, designing constitutional dialogue is essential to make the Separation of Powers practical.

The defended dialogic theory cannot overcome the problematic of judicial review completly, and for such the vision that "the role of the courts in defending individual rights must remain"6263 is still a diagnostics that wasn't overcame completely by any theory. A good dialogic theory is one that integrates both society and its institutions, but living up to such theory is still only a dialogic promise.

\section{FINAL CONSIDERATIONS}

The Separation of Powers presented here was as one of several possible political choices within the political choice denominated constitutionalism, which works under the Rule of Law. The Rule of Law can be seen as a process and it communicates with the Separation of Powers. The process constitutes of diffusion, internalization, supervision, inspection and judgment. It is a vitally important process, but also idealized. The Separation of Powers provides how this process would happen, and for such, would be one of the essential principles for a functional institutional articulation in a Rule of Law. In this way, the Rule of Law implies a requirement for the adequate participation of each of these powers in accordance with their established prerogatives.

What is intended, then, is a distinction of the integrity of each of the powers, theoretically creating a scenario in which it is possible for the subjects to confront the political power in different ways within a Rule of Law. Thus, articulated governance through successive phases maintains its own integrity, through the distinction and maintenance of the powers themselves, ensuring the dignity of the legislation, the independence of the judiciary and the administrative authority of the executive.

gações Constitucionais, Curitiba, vol. 1, n. 3, p. 59-90, set./dez. 2014.

60 VALLE, Vanice Regina Lírio do. Dialogical constitutionalism manifestations in the Brazilian judicial review. Revista de Investigações Constitucionais, Curitiba, vol. 1, n. 3, p. 59-90, set./dez. 2014. p. 84.

61 GARCIA, Jean-René. Montesquieu y la Separacion "del" Poder en America Latina. Perfiles de las Ciencias Sociales, [s.I.], n. 2, p. 125-156, 2014. p. 154.

62 VILE, Maurice J. C. Constitutionalism and the separation of powers. Indianapolis: Liberty Found. Inc., 1998. p. 403.

63 Although Vile makes such statement with the Administrative State in mind, it is still a shared point view with the present work. It also supports the affirmation that no current theory can completely overcome the role of the judiciary in reviewing. 
However, such conception is idealized for it overlooks what happens in the real world. For example, Courts not only more strongly review actions than other powers, but they also say constitutional meaning and create Law. The practice of Law has moved away from such a hard and rigid conception of the Separation of Powers, and therefore, there is a need to adapt the theory to new problems, instead of just go waving goodbye at it. In this scenario, the dialogic theories come forth with great potential to overcome these difficulties. The possibility of equilibrium and partnership between powers through dialogue seems to be a reasonable end to pursue, even though it takes an institutional maturity that is still to be achieved; there is also the need of a delimitation for a more precise concept of dialogue.

Combining democracy and different institutions is an important step in order to promote more effectively different interests. Still, a warning must be held in the sense of also not falling in an idealization: will dialogue always be possible? Such question still remains open, and possibly can only be answered through trial and error. Nevertheless, steps have been taken to shed new light on the Separation of Powers. Understanding how it works in the idealized vision is important to make sure we know where we want to take it, how we can implement it and what developments we still need to work on.

\section{REFERENCES}

BATEUP, Christine. The Dialogic Promise: Assessingthe normative potential of theories of the constitucional dialogue. New York University Public Law and Legal Theory Workin Papers, New York, p. 1-85, 2005.

BRASIL. Constituição da República Federativa do Brasil de 1988. Disponível em: <http://www. planalto.gov.br/ccivil_03/constituicao/constituicao.htm>. Acesso em: 18 ago. 2016

BRASIL. Lei $\mathbf{n}^{\mathbf{9}} \mathbf{9 . 6 0 5}$, de 12 de fevereiro de 1998. Dispõe sobre as sanções penais e administrativas derivadas de condutas e atividades lesivas ao meio ambiente, e dá outras providências. Disponível em: <http://www.planalto.gov.br/ccivil_03/leis/L9605.htm>. Acesso em: 10 set. 2017.

BRASIL. Lei $\mathbf{n}$. 10.220/2001. Institui normas gerais relativas à atividade de peão de rodeio, equiparando-o a atleta profissional. Diário Oficial da União, Poder Executivo, Brasília, 12 abr. 2001.

BRASIL. Supremo Tribunal Federal. ADIN no 4.983. Requerente: Procurador-Geral da República. Requeridos: Governador do Estado do Ceará e Assembleia Legislativa do Estado do Ceará. Relator: Min. Marco Aurélio. Disponível em: <http://www.stf.jus.br/portal/processo/verProcessoAndamento.asp?incidente $=4425243>$. Acesso em: 5 ago. 2017.

BRASIL. Supremo Tribunal Federal. ADIN n 5728. Requerente: Fórum Nacional de Proteção e Defesa Animal. Requeridos: Mesa da Câmara dos Deputados e Mesa do Senado Federal. Relator: Min: Dias Toffoli. Disponível em: <http://stf.jus.br/portal/processo/verProcessoAndamento.asp?numero $=5728 \&$ classe $=A D I \&$ origem $=A P \&$ recurso=0\&tipoJulgamento $=M>$. Acesso em 20 out. 2017. 
BRASIL. Supremo Tribunal Federal. MS 34802 MC. Impetrante: Marcelo Henrique Teixeira Dias. Impetrado: Presidente da Câmara dos Deputados. Relator: Min. Ricardo Lewandowski. Disponível em: <http://s.conjur.com.br/dl/acao-rito-pec-vaquejada-inviavel.pdf>. Acesso em 7 set. 2017.

BONILLA-MALDONADO, Daniel Eduardo. La Arquitectura Conceptual del Principio de Separación de Poderes. Vniversitas, [s.I.], n. 131, p. 231-276, 2015.

BRITO, Renan Moreira de Norões. Lei 15.299 de 2013/CE: consagração do direito fundamental à liberdade de manifestação cultural ou legitimação dos maus tratos contra animais?. Planeta Amazônia: Revista Internacional de Direito Ambiental e Políticas Públicas, Macapá, n. 6, p. 69-83, 2014.

BUNCHAFT, Maria Eugenia; LIMBERGER, Têmis; CRISTIANETTI, Jessica. O refluxo em Roe versus Wade: uma reflexão à luz do diálogo entre constitucionalismo democrático e minimalismo judicial. Pensar - Revista de Ciências Jurídicas, v. 21, n. 3, p. 987-1011, set./dez. 2016.

CAMPOS, Carlos Alexandre de Azevedo. Dimensões do Ativismo no STF. Rio de Janeiro: Forense, 2014.

CEARÁ. Lei n. 15.299/2013. Regulamenta a vaquejada como prática desportiva e cultural no Estado do Ceará. Diário Oficial do Estado, Poder Executivo, Ceará, 8 jan.2013.

CORVALÁN, Juan G. Los ejes centrales de la división de poderes en el Estado Constitucional de Derecho. Revista de Investigações Constitucionais, Curitiba, vol. 2, n. 1, p. 225-256, jan./abr. 2015. DOI: http://dx.doi.org/10.5380/rinc.v2i1.43661

GARCIA, Jean-René. Montesquieu y la Separacion "del" Poder en America Latina. Perfiles de las Ciencias Sociales, [s.I.], n. 2, p. 125-156, 2014.

GRUBBA, Leilane Serratine; CADORE, Caroline Bresolin Maia. Proteção ao meio ambiente, aos animais e o direito à cultura: a aplicação da fórmula do peso refinada de Robert Alexy. Revista Brasileira de Direito Animal. Salvador, v.12, n. 02, p. 193-219, mai./ago. 2017.

GORDILHO, Heron José de Santana; FIGUEIREDO, Francisco José Garcia. A vaquejada à luz da Constituição Federal. Revista de Biodireito e Direito dos Animais, Curitiba, v. 2, n. 2, p. 78-96, Jul./Dez. 2016.

HONNETH, Axel. The Struggle for Recognition: The Moral Grammar of Social Conflicts. Cambridge: The MIT Press, 1996.

KLARMAN, Michael. How Brown changed race relations: the backlash thesis. The Journal of American History, v. 81, n. 1, p. 81-118, 1994. Disponível em <www.jstor.org/stable/2080994>. Acesso em: 13 set. 2017.

KLARMAN, Michael. Courts, Social Change, and Political Backlash. In: Hart Lecture at Georgetown Law Center, 31 Mar. 2011. Speaker's Notes. Disponível em: <http://scholarship.law.georgetown.edu/hartlecture/2>. Acesso em: 13 set. 2017. 
KLATT, Matthias. Direitos a prestações positivas: quem deve decidir? Controle judicial ponderado. In: ALEXY, Robert; BAEZ, Narciso Leandro Xavier; SILVA, Rogério Luiz Nery da (org.). Dignidade humana, direitos sociais e não-positivismo inclusivo. Trad. Carlos Luiz Strapazzon. Florianópolis, 2015. p. 215-266.

LOCKE, John. Two Treatises of Government. Cambridge: Cambridge University Press, 1988.

MENDES, Conrado Hübner. Not The Last Word, but Dialogue: Deliberative Separation of Powers II. Legisprudence, [s.I.], v. 3, n. 2, p. 191-246, 2009.

MEYER-PFLUG Samantha Ribeiro; CAMARGO, M. L. M. S.. O ativismo judicial e a tripartição de poderes. E-CIVITAS, v. IX, p. 153-174, 2016.

MIRANDA, Jorge. Teoria do estado e da constituição. Rio de Janeiro: Forense, 2003.

MONTESQUIEU, Charles Louis de Secondat. Do espírito das Leis. São Paulo: Martins Fontes, 2000.

MÖELLERS, Christoph. The Three Branches: A Comparative Model of Separation of Powers. Cambridge: Oxford University Press, 2013.

MUTH, John. Rational Expectations and the Theory of Price Movements. Econometrica, [s.l.], v. 29, p. 315-335, 1961.

POST, Robert; SIEGEL, Reva. Roe Rage: democratic constitutionalism and backlash. Harvard Civil Rights-Civil Liberties Law Review, v. 42, p. 373-433, 2007. Disponível em <https://law.yale.edu/ system/files/documents/pdf/Faculty/Siegel_RoeRageDemocraticConstitutionalismAndBacklash. pdf> Acesso em: 12 set. 2017.

ROCHA, Manoel Ilson Cordeiro. Estado e governo: diferença conceitual e implicações práticas na pós-modernidade. Revista UNIARA, [s.I.], v. 21/22, p. 140-145, 2009.

SIEGEL, Reva. Same-sex marriage and backlash: constitutionalism through the lens of consensus and conflict. Max Weber Lecture, n. 04, 2016. Disponível em: <http://diana-n.iue.it:8080/handle/1814/41324>. Acesso em 18 ago. 2017.

SILVA, Tagore Trajano de Almeida; VIEIRA, Laira Correia de Andrade. A inconstitucionalidade da vaquejada: uma análise da dignidade animal sobre a ADI nº. 4983 e a lei estadual nº.15.299/13.

AREL FAAR, Ariquemes, v. 4, n. 3, p. 42-60, set. 2016.

SIQUEIRA FILHO, Valdemar; LEITE, Rodrigo de Almeida; LIMA, Victor Breno de. A prática da vaquejada em xeque: considerações sobre a ação direta de inconstitucionalidade $n^{\circ} 4.983$. Revista Brasileira de Direito Animal, Salvador, v. 10, n. 20, p. 59-80, set./dez. 2015.

VILE, Maurice J. C.. Constitutionalism and the separation of powers. Indianapolis: Liberty Found. Inc., 1998.

WALDRON, Jeremy. The Concept and the Rule of Law. Public Law and Legal Theory Research Paper. Working Papers n. 08-50, 2008. 
WALDRON, Jeremy. Separation of Powers in Thought and Practice. Boston College Law Review, Boston, v. 52, n. 2, p. 433-468, 2013.

WALDRON, Jeremy. Political Political Theory: Essays on Institutions. Cambridge: Harvard University Press, 2016. 